\title{
Sistem Pengaman Sepeda Motor Anti Begal
}

\author{
Joni Dewanto ${ }^{1^{*}}$, Felix Tanuwijaya ${ }^{2}$ \\ 1,2 Program Teknik Otomotif, Fakultas Teknologi Industri, Universitas Kristen Petra \\ Jl.Siwalankerto 121-131, Surabaya 60236, Indonesia \\ * Penulis korespondensi; E mail: jdwanto@petra.ac.id
}

\begin{abstract}
ABSTRAK
Saat ini marak terjadi pembegalan sepeda motor yang dilakukan tidak hanya dengan mengancam, tetapi juga melukai bahkan membuat korban begal tidak berdaya. Oleh karena itu perlu pengaman tambahan pada sepeda motor yang dapat menggagalkan aksi begal tersebut. Paper ini memaparkan sistem pengaman anti begal dengan memanfaatkan sinyal bluetooth. Sinyal tersebut digunakan sebagai media penghubung untuk mengaktifkan sistem pengaman yang dipasang pada sepeda motor dengan handphone korban. Sistem pengaman yang dirancang berupa alarm dan sistem mematikan mesin sepeda motor. Pada saat terjadi begal sistem bekerja secara otomatis, yaitu ketika jarak antara korban dan sepeda motor lebih besar dari $10 \mathrm{~m}$. Dengan demikian sepeda motor tidak dapat dibawa begal. Bunyi alarm diharapkan akan menarik perhatian masyarakat untuk datang membantu korban. Sedang pada saat ditinggal di tempat parkir, sistem ini sekaligus juga dimanfaatkan sebagai sistem pengaman tambahan yang bekerja secara elektronik. Sistem pengaman ini dirancang menggunakan perangkat pengatur Arduino pro mikro dengan bahasa pemrograman $\mathrm{C}++$ yang telah disederhanakan. Rancangan sistem pengaman ini sudah diimlementasikan di sepeda motor Honda Blade Repsol tahun 2012, dan dilakukan uji fungsi serta keandalan sistem. Hasil pengujian menunjukkan bahwa sistem dapat bekerja dengan baik dan memiliki keandalan yang tinggi.
\end{abstract}

Kata kunci: Bluetooth; begal; sepeda motor; sistem pengaman.

\begin{abstract}
Nowadays there is a lot of motorcycle hijacking which is done not only by threatening, but also injuring and even leaving victims helpless. Therefore, additional safety on a motorcycle that can thwart the action of the hijacking is needed. This paper describes an anti-hijacking security system which operates by utilizing bluetooth signal. The signal is used as a connecting medium to activate the safety system installed on the motorcycle with the victim's handphone. The proposed security system comprises alarm and motorcycle engine turning off-mechanism. When the hijacking happens, the security system automatically works, i.e. when the distance between victim and motorcycle is greater than $10 \mathrm{~m}$. With this scenario, thus the motorcycle can not be hijacked. Moreover, the sound of alarm is to attract public attention and, in turn, make public help the victim. In parking lot, this security system also functions as an additional security system that works electronically. Within the safety system, an Arduino pro microcontroller with simplified $\mathrm{C}++$ programming language is the basis for its operation. This proposed safety system has been implemented on the Honda Blade Repsol 2012 where its functionality and reliability are also tested. The test results show that the buffer system works well and has high reliability.
\end{abstract}

Keywords: Bluetooth; hijacking; motorcycle; safety system.

\section{PENDAHULUAN}

Di Indonesia, sepeda motor merupakan moda transportasi yang paling popular, dimana hampir setiap warga masyarakat perlu memiliki. Namun demikian, faktanya hal tersebut juga mengakibatkan maraknya kasus pencurian dan begal sepeda motor. Berbeda dari kasus pencurian, kasus begal sepeda motor merupakan aksi perampasan dengan ancaman bahkan tindak kekerasan terhadap korban. Dalam kondisi demikian beberapa alat pengaman yang dikembangkan pabrikan masih terbatas pada sistem pengamanan untuk meninggalkan sepeda motor ditempat parkir. Biasanya berupa kunci kontak dan kunci stir dengan berbagai modifikasinya $[1,2,3]$. Pada kasus begal, semua peralatan pengaman tersebut tidak dapat diandalkan. Pada saat terjadi begal, biasanya mesin sepeda motor dalam kondisi hidup dan atau semua sistem pengaman sepeda motor dalam keadaan tidak terkunci sehingga 
sepeda motor korban dengan mudah dapat dibawa lari oleh pelaku begal. Terlebih ketika korban begal dalam kondisi tidak berdaya dan tidak mungkin dapat mempertahankan sepeda motornya dari aksi perampasan.

Oleh karena itu perlu diciptakan sistem pengaman sepeda motor khususnya untuk mengantisipasi bila terjadi kasus begal. Adapun sistem pengaman yang dirancang dan dipaparkan dalam paper ini bekerja dengan menggunakan sinyal bluetooth yang berfungsi sebagai media penghubung untuk mengaktifkan sistem pengaman yang dipasang pada sepeda motor dan handphone korban. Sistem pengaman yang dimaksud berupa alarm suara klakson, nyala lampu dan sistem mematikan mesin sepeda motor. Sistem ini bekerja secara otomatis menggunakan perangkat pengatur Arduino pro mikro dengan bahasa pemrograman $\mathrm{C}++$ sederhana. Sesuai jarak jangkau pancaran sinyal bluetooth, maka sistem ini akan bekerja ketika jarak antara korban dan sepeda motor sudah lebih dari $10 \mathrm{~m}$. Selanjutnya sistem pengaman ini diimplementasikan pada sepeda motor Honda Blade Repsol tahun 2012.

\section{METODE PENELITIAN}

Metode dan alur penelitian yang dilakukan secara skematik ditunjukkan seperti Gambar1.

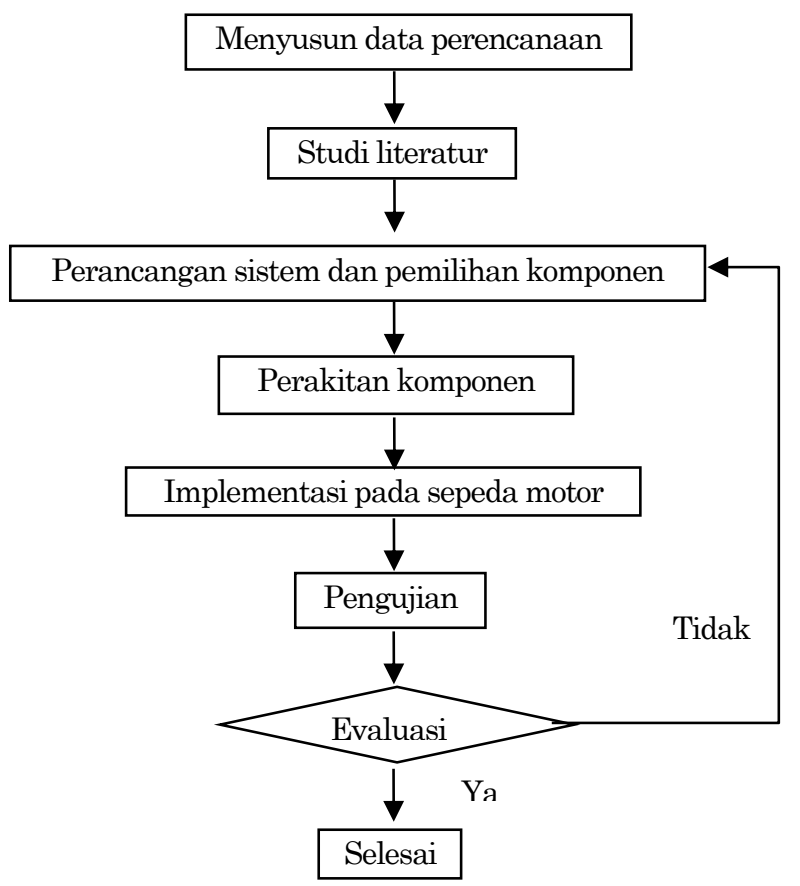

Gambar 1. Tahapan penelitian

Langkah pertama dalam penelitian dan perancangan ini adalah melakukan studi terhadap peralatan pengaman dan sistem kelistrikan khususnya pada sistem pengendalian (mematikan dan menghidupkan) mesin sepeda motor yang telah ada [4]. Langkah ini dimaksudkan agar ada sinkronisasi antara sistem yang sudah ada dan sistem yang ditambahkan sehingga peralatan pengaman yang sudah ada dapat diaktifkan dan dimaksimalkan fungsinya secara otomatis.

Selanjutnya pada tahap perancangan dilakukan pemilihan komponen yang memungkinkan untuk ditambahkan pada jalur kelistrikan dari sistem pengapian mesin motor. Adapun perangkat yang digunakan yaitu microcontroller Arduino pro mikro dan relay module 4 channel. Perangkat ini memiliki ukuran cukup kompak sehingga untuk pemasangannya tidak banyak memakan tempat dan oleh karena itu dapat diletakkan di bagasi sepeda motor.

Selanjutnya sistem pengaman dirancang dengan skema kerja seperti terlihat pada Gambar 3. Semua komponen dirakit dan diimplementasikan pada sepeda motor. Dilakukan uji fungsi dari setiap komponen dan uji sistem secara menyeluruh, termasuk juga uji koneksitas dengan handphone pengguna sepeda motor. Pengujian dilakukan secara berulang untuk memastikan keandalan sistem.

\section{HASIL DAN PEMBAHASAN}

Bagian utama dari sistem pengaman dengan sinyal bluetooth terdiri dari microcontroller Arduino, relay module 4 channel, DC module step down, serta bluetooth module. Perangkat-perangkat tersebut disusun menjadi sebuah rangkaian elektronik yang diletakkan pada sebuah box transparan. Alat tersebut menyerupai kotak alarm, namun dengan dimensi yang sedikit lebih besar dan dapat diletakkan di bawah jok sebagaimana ditunjukkan Gambar 2.

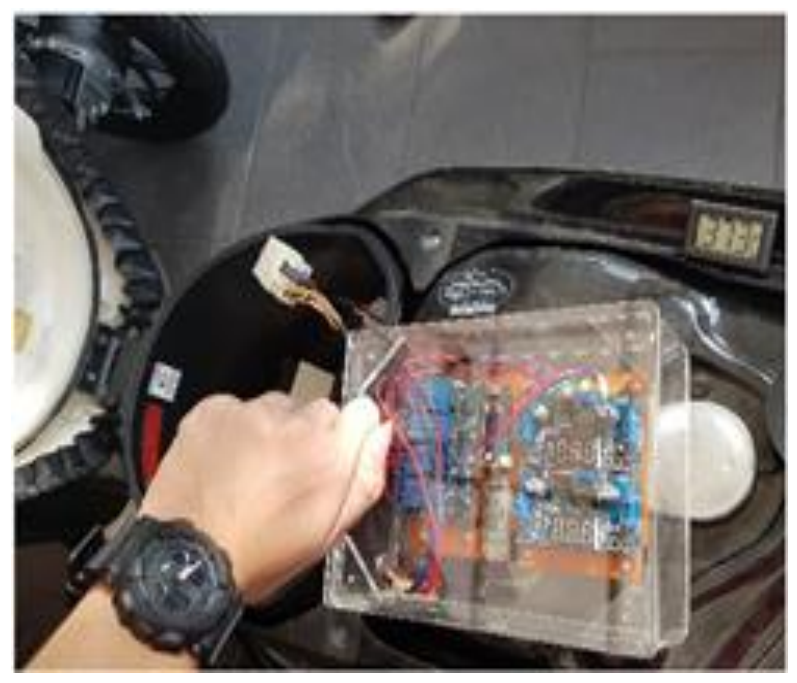

Gambar 2. Peletakan modul sistem pengaman

Koneksi antara perangkat sistem pengaman dengan sepeda motor dibuat dengan menggunakan socket to socket sehingga memudahkan pengguna apabila ingin melepas dan memasang alat tersebut. 
Pada dasarnya sistem ini membutuhkan konektivitas antara kedua bluetooth yakni bluetooth pada alat dengan bluetooth pada handphone pengendara sepeda motor yang kemudian input sinyal tersebut diolah oleh microcontroller untuk memerintahkan relay memutus atau menyambung koneksi sistem pengapian pada CDI sepeda motor. Sehingga, apabila sistem pengaman tersebut dilepas dari sepeda motor, koneksi kelistrikan sistem pengapian tetap akan terputus dan mesin tidak akan dapat dinyalakan kembali sebelum dilakukan jumper pada socket CDI. Kabel jumper ini sudah disediakan dan berfungsi untuk mengantisipasi apabila terjadi problem seperti: bluetooth error maupun baterai handphone habis. Dengan demikian, sepeda motor tetap dapat dinyalakan dan dikendarai secara normal tanpa menggunakan sistem pengaman. Sistem ini cukup mudah untuk digunakan pengendara sepeda motor namun cukup sulit untuk dimengerti oleh pencuri.

Sistem pengaman dengan sinyal bluetooth sendiri ini terdiri dari beberapa komponen. Komponenkomponen dalam sistem pengaman dengan sinyal bluetooth adalah sebagai berikut:

1. Microcontroller Arduino Micro - Leonardo

2. Bluetooth Module HC-05

3. 4 Channel Relay Module 5 Volt

4. DC Module Step Down X2

5. $L E D$

6. PCB kosong

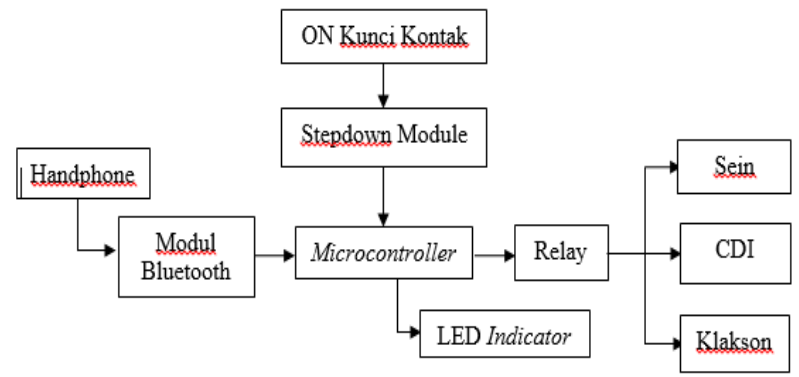

Gambar 3. Skema cara kerja sistem pengaman

\section{Rancangan Sistem}

Microcontroller akan mendapatkan tegangan listrik secara langsung dari aki, termasuk juga relay dan bluetooth. Hal ini bertujuan agar sistem langsung beroperasi serentak sehingga koneksi dengan handphone tidak memerlukan waktu lama dan alarm tetap dapat berbunyi sekalipun kontak dimatikan. ON kunci kontak diperlukan sebagai inputan bagi microcontroller untuk mengetahui kondisi mesin dalam keadaan ON atau OFF. Hal ini berfungsi ketika posisi OFF dan bluetooth dinyalakan, maka sistem tidak akan memerintahkan alarm untuk berbunyi.

Karena listrik pada sepeda motor memiliki tegangan 12 Volt, sedangkan microcontroller bekerja pada tegangan 5 Volt maka diperlukan stepdown module dari jalur listrik $\mathrm{ON}$ sepeda motor menuju ke microcontroller. Juga satu buah stepdown tambahan untuk menyalakan sistem secara keseluruhan dengan input langsung dari aki. Microcontroller akan bekerja sesuai program yang telah dimasukkan ke dalam memory pada microcontroller.

Untuk menjalankan sistem ini dengan baik, bluetooth pada handphone perlu diaktifkan dan harus dilakukan pairing terlebih dahulu dengan bluetooth module HC-05 [5]. Cara melakukan bluetooth pairing pada sistem ini layaknya pairing antara 1 bluetooth device dengan bluetooth device lainnya. Misalnya seperti handphone pairing dengan bluetooth speaker dimana untuk melakukan pengaturan pairing tersebut, maka kedua bluetooth terlebih dahulu diaktifkan dan selanjutnya masuk ke menu setting dari bluetooth yang tertera pada handphone dengan memilih bluetooth mana yang muncul dan ingin dilakukan pairing [6].

Karena status paired belum menjamin terjadinya komunikasi antara kedua bluetooth (receiver dan transmitter), maka diperlukan juga software tambahan pada handphone berbasis Android yakni Bluetooth Terminal dimana software ini dapat diunduh secara gratis bagi pengguna handphone berbasis Android pada playstore [7]. Software ini diperlukan sebagai layaknya jembatan agar bluetooth handphone dan bluetooth module HC-05 dapat berkomunikasi dengan baik. Karena software ini bersifat free (gratis), yang berarti semua orang dapat secara bebas melakukan download, sehingga dikhawatirkan apabila ada pihak yang tidak bertanggung jawab menggunakan software yang ada untuk cloning (mengambil alih atas koneksi bluetooth sistem dengan bluetooth handphone pemilik kendaraan). Oleh karena itu ditambahkan kata sandi khusus yang dapat diprogram sehingga untuk melakukan koneksi antara sistem dengan handphone selain harus menggunakan software Bluetooth Terminal juga harus memasukkan kata sandi ketika melakukan pairing yang sebelumnya sudah diberikan program pada Arduino. Apabila tidak, maka bluetooth tidak dapat berkoneksi.

Apabila sepeda motor hendak dinyalakan (kunci kontak diputar dari posisi OFF ke ON), otomatis sistem akan menyala dan terus mencari sinyal bluetooth yang ada di sekitar. Hal ini ditandai dengan LED kecil pada modul bluetooth yang terus berkedip cepat. Apabila telah ditemukan sinyal bluetooth yang telah dilakukan paired sebelumnya, dan software Bluetooth Terminal pada handphone dinyalakan, maka otomatis bluetooth module akan menjalin koneksi dengan handphone yang ditandai dengan LED kecil. Bluetooth akan berkedip konstan $2 \mathrm{x}$ setiap 1 detik dan diiringi dengan microcontroller memerintahkan LED indicator untuk menyala sebagai simbol bahwa sistem terkoneksi dengan baik. 
Dengan terkoneksinya bluetooth, maka microcontroller akan memberi sinyal 5 Volt ke relay untuk menutup rangkaian kelistrikan pada CDI sehingga sistem starter dapat berfungsi dengan normal dan mesin hidup sebagaimana mestinya. Sebaliknya apabila tidak ada koneksi bluetooth ketika mesin hendak dihidupkan, dan kunci kontak diputar pada posisi ON lalu dipaksa starter maka microcontroller akan memberi sinyal 5 Volt pada relay dan memerintahkan relay untuk mengaktifkan hazard yang berkedip selama kurang lebih 1 menit dan dilanjutkan dengan klakson yang berbunyi.

Demikian juga apabila dalam posisi berkendara (bluetooth sudah terkoneksi dan mesin hidup), lalu tiba-tiba terjadi kasus begal dan sepeda motor dibawa lari oleh maling, jarak maksimal yang bisa dijangkau oleh bluetooth module HC-05 dengan bluetooth pada handphone adalah 10 meter. Setelah melewati 10 meter maka bluetooth module akan kehilangan koneksi dan tetap terus mencari koneksi yang ada. Pada keadaan ini maka sinyal 5 Volt yang diberikan relay kepada CDI akan hilang. Ketika ini terjadi microcontroller juga akan memberikan sinyal 5 Volt ke relay sein untuk mengaktifkan hazard selama 45 detik dan memberikan sinyal 5 Volt lagi ke relay klakson untuk mengaktifkan klakson setelah hazard menyala selama 45 detik. Setelah hazard berkedip selama 45 detik, maka mesin akan otomatis mati, sesuai dengan rangkaian program yang telah dimasukkan ke memory microcontroller. Klakson yang berbunyi tidak akan bisa berhenti sebelum sistem dilakukan reset kembali. Cara untuk melakukan reset sistem ini sendiri yakni dengan syarat ada bluetooth yang terkoneksi kembali dengan bluetooth module hingga lampu LED indicator pada sistem menyala. Selanjutnya diikuti dengan memutar kunci kontak ke posisi ON - OFF secara perlahan selama 3 kali. Apabila berhasil melakukan reset sistem maka alarm akan berhenti, dan motor dapat dilakukan starter dengan normal. Diagram rangkaian dari sistem pengaman tersebut ditunjukkan pada Gambar 4.

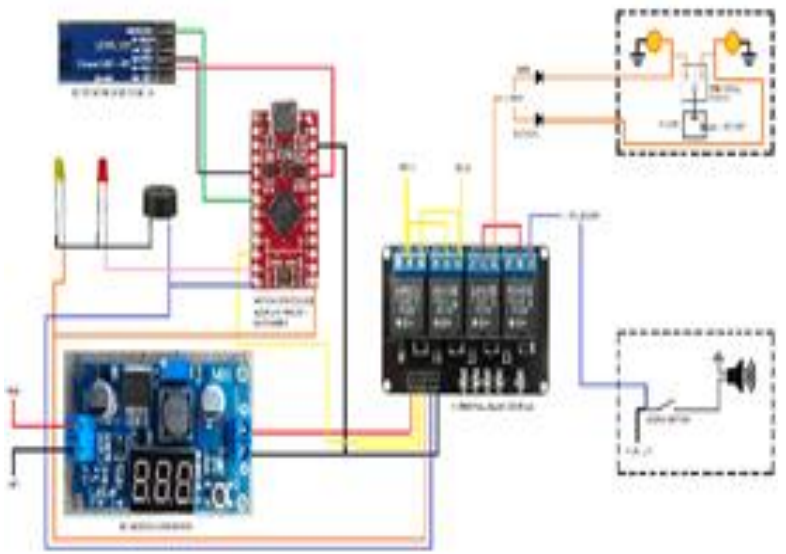

Gambar 4. Diagram rangkaian kelistrikan sistem pengaman

\section{Pengujian}

Pengujian ini dimaksudkan untuk mengetahui unjuk kerja sistem yang telah dirancang dan diterapkan di kendaraan. Pengujian ini meliputi uji fungsi dan koneksitas bluetooth, yaitu untuk memastikan apakah sistem dan peralatan dapat berfungsi sebagaimana kondisi yang dirancang. Pengujian juga dilakukan pada kondisi cuaca yang berbeda untuk memastikan bahwa sinyal bluetooth yang digunakan tetap memiliki keandalan dalam berbagai kondisi cuaca. Pengujian dilakukan pada waktu pagi, sore, malam hari, dan ketika hujan dimana suhu dan kelembaban udaranya berbeda.

Dalam proses pengujian ini, terlebih dahulu dilakukan pencarian data yakni Dry Bulb dan Wet Bulb Temperature. Hal ini digunakan untuk menghitung Relative Humidity (\%RH) yang dapat diperoleh melalui bantuan Psychometric Chart dengan memotongkan dua titik yakni antara Dry Bulb dan Wet Bulb Temperature. Pengujian Dry Bulb dilakukan dengan menggunakan termometer ruangan yang ujung bulb dibiarkan terbuka tanpa dilapisi sesuatu, sedangkan Wet Bulb dilakukan dengan memberi kapas yang telah dibasahi lalu diikat pada ujung bulb. Selanjutnya pengujian waktu dilakukan ketika bluetooth pada handphone tepat dinyalakan, bersamaan dengan kunci kontak diputar ke posisi ON dan timer dengan menggunakan stopwatch untuk melihat berapa waktu yang diperlukan bagi kedua bluetooth untuk berkoneksi.

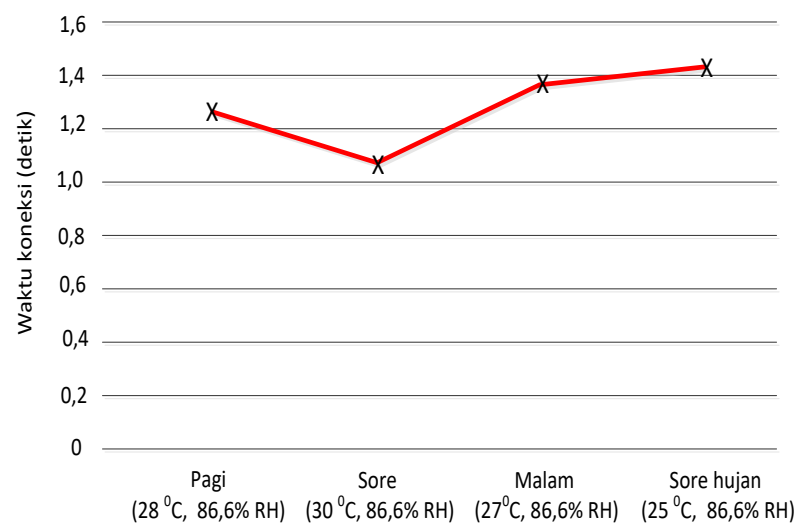

Gambar 5. Hasil uji keandalan sistem terhadap cuaca.

Dari hasil percobaan diperoleh bahwa waktu yang diperlukan bagi kedua bluetooth untuk dapat berkoneksi tidak lebih dari 2 detik sebagaimana ditunjukkan Gambar 5. Berdasarkan percobaan pengujian terhadap cuaca (kelembaban), maka dapat disimpulkan bahwa cuaca (suhu dan kelembaban) udara tidak mempengaruhi lama waktu konektivitas sinyal bluetooth.

Pengujian berikutnya adalah pengujian sensitifitas sinyal bluetooth. Pengujian ini berfungsi untuk 
mengetahui jarak efektif bluetooth sistem untuk tetap stabil dalam berkoneksi dengan bluetooth handphone pengguna, dan juga untuk mengetahui normal tidaknya sistem yakni apakah alarm berfungsi dengan baik atau tidak. Pengujian ini dilakukan dalam dua kondisi yakni ketika dalam keadaan normal dimana mesin mati dan akan dihidupkan.

Pada percobaan ini, bluetooth pada handphone dinyalakan secara berurutan ketika handphone dan alat pada sepeda motor berada pada jarak 1 hingga 10 meter. Berdasarkan percobaan yang dilakukan, maka pada jarak 1 hingga 7 meter bluetooth pada sistem dapat mendeteksi adanya koneksi dari bluetooth handphone sehingga mesin dapat diberikan starter dan sein serta klakson tidak menyala. Selanjutnya, pada jarak 8 hingga 10 meter didapati bahwa ketika bluetooth pada handphone dinyalakan pada jarak tersebut, sistem pengaman pada sepeda motor tidak dapat mendeteksi sinyal bluetooth yang ada sehingga sistem starter pun baik kick starter maupun electric starter tidak berfungsi. Demikian pula pada kondisi ini, sein dan klakson tetap tidak menyala sekalipun tidak ada koneksi bluetooth yang tersambung karena sistem membaca bahwa kondisi mesin masih dalam keadaan mati (belum sempat dinyalakan sama sekali). Dapat disimpulkan bahwa sistem berfungsi dengan normal tanpa ada error.

Pengujian selanjutnya yakni pada kondisi mesin sudah hidup dan bluetooth dimatikan. Pada kasus ini bluetooth pada handphone sudah sempat terkoneksi dengan bluetooth pada alat. Lalu dengan memberi jarak 1 hingga 10 meter antara handphone dengan alat, dilakukan pengamatan pada jarak berapakah koneksi bluetooth terputus. Berdasarkan hasil pengujian, pada jarak 1 hingga 9 meter bluetooth pada handphone tetap dapat berkoneksi dengan bluetooth pada alat sehingga mesin tetap menyala dan sein serta klakson nonaktif. Namun ketika jarak antara handphone dan alat pada sepeda motor telah mencapai 10 meter, didapati bahwa koneksi kedua bluetooth terputus sehingga mengakibatkan mesin tetap hidup selama 45 detik sejak koneksi terputus dan diiringi dengan sein serta klakson yang menyala. Setelah itu, apabila mesin telah mati, maka mesin tidak dapat diberikan starter kembali sekalipun bluetooth dikoneksikan ulang. Untuk mengatasi hal tersebut, maka perlu dilakukan reset dengan kunci kontak sebanyak 3 kali agar sistem normal kembali.

Kedua pengujian tersebut dilakukan secara berulang sehingga juga sekaligus menguji sistem yang dirancang terhadap frekuensi penggunaan. Hasil pengujian selama total 43 kali pengujian, menunjukkan tidak ada kerusakan atau error pada sistem sehingga dapat dipastikan bahwa sistem dapat bekerja sebagaimana kondisi yang dirancang dan memiliki keandalan yang tidak terpengaruh oleh cuaca atau kondisi lingkungan.

\section{KESIMPULAN}

Sistem pengaman sepeda motor dengan sinyal bluetooth telah dirancang untuk bekerja secara otomatis apabila terdapat sinyal bluetooth pada handphone yang sudah terkoneksi dengan sistem dan sekaligus memproteksi apabila terjadi kasus begal dimana pada jarak tertentu sistem akan memutus rangkaian kelistrikan pada CDI sepeda motor sehingga mesin akan mati. Demikian ketika hendak dinyalakan paksa tanpa adanya sinyal bluetooth yang terkoneksi, maka sistem akan mengaktifkan alarm pada sepeda motor.

Dari hasil pengujian, sistem pengaman sepeda motor dengan sinyal bluetooth telah bekerja dan berfungsi dengan baik sesuai yang diinginkan dimana sistem ini telah diuji selama beberapa kali dan terbukti bahwa sinyal bluetooth tidak terpengaruh terhadap cuaca. Hal ini dibuktikan dengan tidak terjadinya error pada saat pengujian yang membuktikan bahwa sistem ini cukup handal, serta aman digunakan untuk pemakaian seharihari. Namun demikian, sistem ini mengandalkan sinyal bluetooth sebagai trigger bagi alat untuk memutus ataupun meyambung jalur kelistrikan pada CDI sehingga apabila terjadi kasus begal dimana sistem dalam keadaan digunakan dan handphone pengendara juga ikut dicuri maka sepeda motor tetap dapat berjalan.

\section{DAFTAR PUSTAKA}

[1]. Artika, K. D., 2013, "Rancang Bangun Sistem Pengaman Pada Sepeda Motor Dengan Memanfaatkan Sensor Encoder dan Sensor Ping". Jurnal Rotor, 6(1), hal. 1-4. (Diunduh dari: http://jurnal.unej.ac.id/index.php/RTR/article/vi ew/1159)

[2]. Rachmat, R. R., Julian, E. S., 2016, "Pengaman Sepeda Motor Berbasis Mikrokontroller", Jurnal Ilmiah Teknik Elektro, 13(2), hal. 1-10.

[3]. Budy, 2011, Sistem Pengamanan Kunci Sepeda Motor Menggunakan Radio Frequency Identification (RFID), Sekolah Tinggi Manajemen Informatika dan Komputer AMIKOM, Yogyakarta, Indonesia.

[4]. Sutiman, 2011, Sistem Pengapian Elektronik, Citra Aji Parama, Yogyakarta, Indonesia.

[5]. HC-05 Bluetooth to Serial Port Module. (Diunduh dari: http://www.electronicaestudio.com/ docs/istd016A.pdf)

[6]. Gangan, P., Joglekar, A., 2015, "Cell Phone Operated Car Using Bluetooth Technology", International Journal of Research in Engineering and Technology, pp. 2319-2322.

[7]. Sakhare, M., Ganer, S., Mulchandani, M., 2015, "Car Remote Locking Via Bluetooth Using Android", International Research Journal of Engineering and Technology, 2(9), pp. 766-767. 